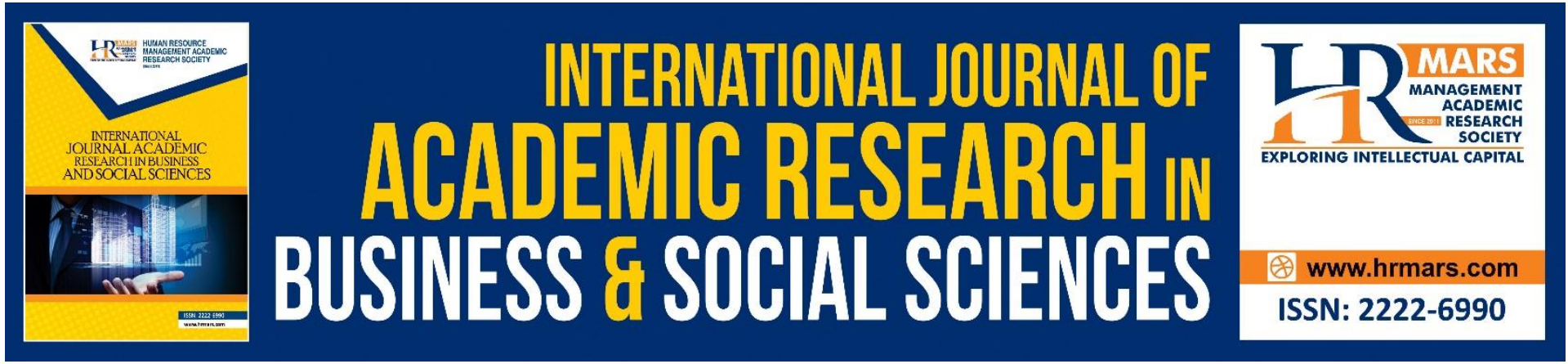

\title{
Intellectual Capital and Innovation Capability: A Conceptualization of Organisation Performance Measurement through Literature Review
}

Logaiswari Indiran, Umar Haiyat Abdul Kohar, Azamat Maksudunov, Shathees Baskaran

To Link this Article: http://dx.doi.org/10.6007/IJARBSS/v11-i6/9845 DOI:10.6007/IJARBSS/v11-i6/9845

Received: 18 April 2021, Revised: 22 May 2021, Accepted: 09 June 2021

Published Online: 30 June 2021

In-Text Citation: (Indiran et al., 2021)

To Cite this Article: Indiran, L., Kohar, U. H. A., Maksudunov, A., \& Baskaran, S. (2021). Intellectual Capital and Innovation Capability: A Conceptualization of Organisation Performance Measurement through Literature Review. International Journal of Academic Research in Business and Social Sciences, 11(6), 1842-1852.

Copyright: (c) 2021 The Author(s)

Published by Human Resource Management Academic Research Society (www.hrmars.com)

This article is published under the Creative Commons Attribution (CC BY 4.0) license. Anyone may reproduce, distribute, translate and create derivative works of this article (for both commercial and non-commercial purposes), subject to full attribution to the original publication and authors. The full terms of this license may be seen

at: http://creativecommons.org/licences/by/4.0/legalcode

Vol. 11, No. 6, 2021, Pg. 1842 - 1852

http://hrmars.com/index.php/pages/detail/IJARBSS

JOURNAL HOMEPAGE

Full Terms \& Conditions of access and use can be found at http://hrmars.com/index.php/pages/detail/publication-ethics 


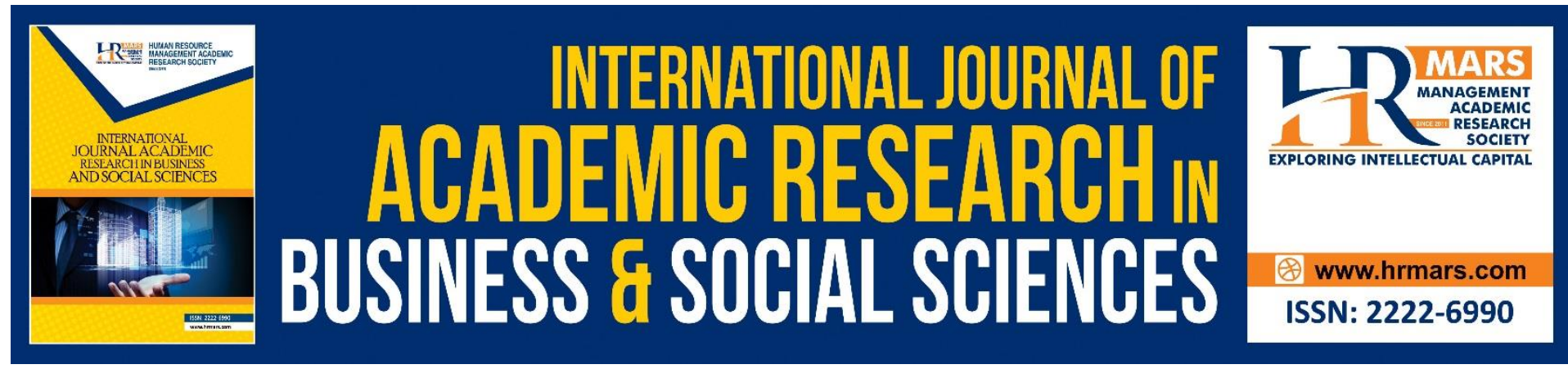

\title{
Intellectual Capital and Innovation Capability: A Conceptualization of Organisation Performance Measurement through Literature Review
}

\author{
Logaiswari Indiran', Umar Haiyat Abdul Kohar², Azamat \\ Maksudunov $^{3}$, Shathees Baskaran ${ }^{4}$ \\ 1,2,4 Universiti Teknologi Malaysia, Malaysia, ${ }^{3}$ Kyrgyz-Turkish Manas University, Kyrgyzstan \\ Email: logaiswari@utm.my
}

\begin{abstract}
In the twenty-first century, intellectual capital and innovation capability have been identified as two of the most significant determinants of organisational performance. However, research into the relationship between intellectual capital, innovation capability, and organisational performance has yielded mixed results due to, several inconsistencies which includes the evaluation measurements used. Therefore, the purpose of this study was to classify and categorise the measurement indicators used in determining organisational performance. The research focuses on several scientific journals that report on organisational efficiency, including both financial and non-financial performance metrics. Studies examining the relationship between intellectual capital, innovation capability, and organisational performance were identified using a literature review approach use focal phenomenon. Articles were categorised and analysed based on how organisational performance was assessed. Financial and non-financial metrics, as well as objective and subjective steps, were used to classify the data. However, it cannot be ignored that multi-dimensional performances are used in some of the most recent literature. Therebefore, this study proposes three steps before deciding on performance indicators; Firstly, researchers should revise commonly used measurements of performance, or the same kinds of instruments for evaluation, and secondly, classify them into financial and non-financial measures or objective and subjective measures. Lastly, integrate those two types of measurement indicators. As a result, researchers will be able to achieve the research objective precisely and contribute to the body of knowledge.
\end{abstract}

Keywords: Intellectual Capital, Innovation Capability, Organisation Performance, Performance Measurement, Literature Review

\section{Introduction}

Organisation performance is used in measuring the quality of an organisation by academia in strategic management research (Tseng et al., 2013), despite the term being a highly debated issue and vary from one scholar to another. Organisation performance is important as it reflects success over a period of time, including in the study related to intellectual capital and innovation capability. It can also be perceived as the process of 
measuring the difference between the expected and actual result (Santos and Brito, 2012). Previous works have traditionally measured organisation performance from the financial context (Huselid, 1995; McWilliams and Siegel, 2000), but time has gradually broadened the concept to allow multi-dimensional measurements (Alrowwad and Abualoush, 2020). According to Venkatraman and Ramanujam (1986), the concept has been categorized into three domains: financial performance, business performance, and organisational effectiveness. Other scholars have also opted to classify it into financial performance and nonfinancial performance (Sethibe and Steyn, 2016; Shin et al., 2014, Alrowwad and Abualoush, 2020). A recent review on measurement instrument for organisation performance in articles related to innovation and organisation performance, Sethibe and Steyn's (2016) classification into the two domains. It also draws attention to the large number of studies that have used subjective or objective metrics to assess organisational efficiency. Through a review of the literature on intellectual capital and innovation capacity, this study will address organisational performance in both financial and non-financial contexts, as well as from the perspectives of objective and subjective measurement.

\section{Problem Statement and Objectives}

Numerous studies have investigated the relationship between intellectual capital and innovation capability and organisation performance. However, due to several variables, including the measurement indicators used to assess organisational performance, the findings are inconclusive. This study examine the dimensions used to assess organisational performance in the study related to intellectual capital and innovation capacity to better explain these inconsistencies. As a result, this research aims to: (i) identify, classify, and categorise the measurement indicators used in determining organisational financial and nonfinancial performance in intellectual capital and innovation capacity domains, as well as (ii) objective and subjective performance.

\section{Literature Review Strategy}

The purpose of this article is to cover 12 years (2008-2020) of literature related to intellectual capital and innovation capabilities and they were examined use focal phenomenon. The main goal of this analysis study is not to identify the relationship of the research, but to observe and classify the type of performance indicator used to measure organisation performance. measurement used. The related articles were found in Google scholars database, with the keywords used; "intellectual capital," "innovation," and "performance". The list of articles that were reviewed is shown in Table 1.

\section{Financial and Non-Financial Performance}

The focus of financial performance is typically on "outcome-based financial indicators that are assumed to reflect the fulfilment of" (Venkatraman and Ramanujam, 1986). Sales growth, financial results, after-tax results, earnings per share (EPS), market price performances, and after-tax profits are among the standard variables used in intellectual capital studies. Besides financial measures such as the return on sales (ROS), return on investment (ROI), return on assets (ROA), and return on equity (ROE), Likar et al. (2014) and Tsao and Lien, (2013) used stock market measures like the price earning (P/E) ratio and Tobin's Q. However, Kamukama et al. (2011) has chosen portfolio risk, net profit ratio, loss ratio, the yield on assets, and net loan book value, while Madinos et al. (2011) went with return on assets and market value. However, many believe that financial measurements only 
reveal past performance and are insufficient for communicating long-term value creation (Kaplan and Norton, 1996). Additionally, data collection for financial measures have also been found to be slightly limited, but a substantial amount of authors in the intellectual capital field have opted for it to be the primary approach in their works regardless (Alrowwad and Abualoush, 2020, Maditinos et al., 2011; Perin et al., 2016; Ranani and Bijani, 2014).

During the late 1980s, financial measurement has been overtaken by non-financial measures as organisations recognized the value of complex concepts like customer and employee satisfaction, image and reputation, branding, and process and production effectiveness. Venkatraman and Ramanujam (1986) point out that firms have different criteria for reporting results on variables such as return on capital and operating profit, as these outcomes measure a firm's economic performance differently. Thus, performance measurement models like the balanced scorecard approach, intellectual capital model, business excellence model, and the performance prism have extended the measurement domain and qualify as a complex non-financial concept (Kaplan and Norton, 1996). Therefore, according to Sethibe and Steyn (2016), employing non-financial performance in a study requires consideration of two main reasons: (1) several groups of interest have specific expectations and goals for an organisation, and (2) not all shows a financial outcome.

Therefore, this has resulted in non-financial metrics indicators, such as market share, product quality, retention, customer satisfaction, productivity, marketing effectiveness, operational effectiveness, reputation, branding, and quality. Moreover, Quink (2008) has also explained how non-financial success is measured through the implementation of innovation strategy, innovation-focused human resource policy, environmental instability, and innovation performance. In their research, Oke et al. (2012) used non-financial measures such as innovation plan execution, innovation-focused human resource policy, environmental instability, and innovation efficiency. A further study by Xiaobo and Sivalan and his colleagues (2013) concluded that they felt the need for a dynamic measurement system examining the link between intellectual capital, ability to innovate, and the effectiveness of the firm.

Then, the early 1990s have displayed adaptations of multi-dimensional performance indication to overcome the weaknesses of unidimensional measurement (Sethibe and Steyn, 2016), by integrating financial and non-financial measurements. Gentry and Shen (2010) examined the relevance of financial and non-financial measures of organisational efficiency when examining the linkages between accounting and market standards of performance. However, it has highlighted that employing financial measures alone is not wrong, but aspects of organisational performance to be studied should be clearly defined and become the core for the development and testing of hypotheses. Meanwhile, many studies have opted to employ multi-dimensional indicators to measure firm performance, as seen in Table 1 . Hsu and Fang (2009) in particular have utilised market performance, financial performance, customer performance, and product performance to measure multidimensional performance. In contrast, Chen et al (2014) has employed two financial items (i.e. relative ROA and relative profitability), two market items (i.e. relative sales and relative market share), and one overall performance item (i.e. meeting objective for customer satisfaction) as indicators for new product development. Additionally, Chen and Wang (2015) use a multidimensional approach to measuring innovation success that includes financial performance, technological skill, and opportunity windows as measurement metrics.

Recently, Sethibe and Steyn (2016) recently published a study of 71 studies that looked at the instruments used to assess organisational success. They were able to identify five (7\%) studies that focused solely on financial components and 29 (41\%) studies that focused solely 
on non-financial measures. The remaining 37 (52\%) studies have combined both to measure organisational performance. They have consequently and conclusively argued the need for researchers to adhere to three steps when measuring organisational performance, which is: (1) the need for a clear definition regarding various aspects of organisational performance before the implementation (Gentry and Shen, 2010); (2) the use of established and tested instruments or indicators often used; and (3) the combination of both objective and subjective measurement indicators of organisational performance that will result in contributions for the body of knowledge. With regards to the second step, an in-depth literature review on performance is crucial before indicator selection to ensure an accurate and comparative gauge for any variations, validity, and reliability of measures (Saunders et al., 2012). Therefore, this study proposed multidimensional measurement which integrated financial and non-financial measurement as one of the best measurements for studies related to intellectual capital and innovation capability.

\section{Objective Versus Subjective Measures}

Measures also can be approached either objectively or subjectively, whereby objective measures firstly refer to the firm's current definite values that reflex the performance (Battor and Battor, 2010). It can be derived from financial data that has been audited, such as asset values, sales, or profit (Kamukama et al., 2011; Rajan and Reichelstein, 2009). Furthermore, absolute values of objective indicators of a company's actual results are typically obtained from a third-party source, such as a stock exchange (Sethibe and Steyn, 2016). However, in most cases, data using objective measures are not easily obtainable due to them being highly confidential and not easily accessible by the public. Therefore, researchers prefer to use subjective measures instead, in addition to using objective measures have yielded a higher number of works generating mixed results either positive, negative or no relationship (Dawes, 1999; Gentry and Shen, 2010; Sethibe and Steyn, 2016). Such circumstances may be attributed to the type of instruments used. For example, when measured using return on equity (ROE), Likar et al. (2014) found that innovation positively significant to performance, whereas when measured using return on assets (ROA), and return on sales (ROS, the same study found no association. Furthermore, according to Chen et al. (2014), objective performance measures for new product development performance are frequently unavailable or inaccurate.

In contrast, subjective measures for firm performance are according to managerial view, whereby respondents are to rate their company's performance against its competitors (Greenley, 1995). Its nature has therefore rendered subjective measures not verifiable in contrast with objective measures, which are verifiable (Rajan and Reichelstein, 2009). However, studies by Oke et al. (2012) and Ritala (2012) have opted for both objective and subjective measurements in their studies correlated to innovation and firm performance. Regardless, many other works opt for subjective measures as audited data is difficult to obtain due to high confidentiality. Moreover, Sethibe and Steyn (2016) have found that 43 out of 71 studies (61\%) have employed subjective measures for organisational performance which shows innovation significantly impacts organisational performance. Besides, Hormiga et al. (2011b) have used subjective self-perception of success from the perspective of the company owner to assess the success of business start-ups. The study included achievement of initial targets, return on investment (ROI), overall performance, and success as the measurement indicators. Additionally, Dawes (1999) has outlined several conditions for the use of subjective measures, which is supported by Singh et al. (2016): 
i. When it relates to studies where organisations are reluctant to disclose actual performance, due to its commercially sensitive or confidential nature.

ii. When it comes to studies that compare profit output in cross-industry studies, profit levels can differ significantly between industries.

iii. Profitability may not accurately reflect a company's underlying financial health; profitability may fluctuate due to factors such as R\&D investment or marketing activity, which can have long-term consequences.

Hence, this study is proposing subjective measures for multidimensional measurement, integrating the financial and non-financial indicators to gauge the organisation performance in studies that are related to intellectual capital and innovation capability. Such a decision is appropriate for the reasons stated above (Singh et al., 2016), alongside the encouragement for researchers to employ multidimensional performance measurement in incubation (Palumbo and Laurenziano, 2013). Thus, respondents can factor in the relative performance shown by the industry when selecting their response ("rank your company compared to the competitors in your industry"). The measurement used by Sharabathi et al. (2010) is business performance, employing productivity, profitability, and market valuation via subjective self-perception. Meanwhile, a study in Turkey used multidimensional, namely qualitative, and quantitative performance (Özer et. al., 2015). Table 1 displays information regarding studies that have discussed the types of measurement and the measurement indicators, respectively. Figure 1 illustrated the discussion of how the indicators used to measure organisation performance are either objective measures or subjective measures using financial performance, non-financial performance, or multi-dimensional performance.

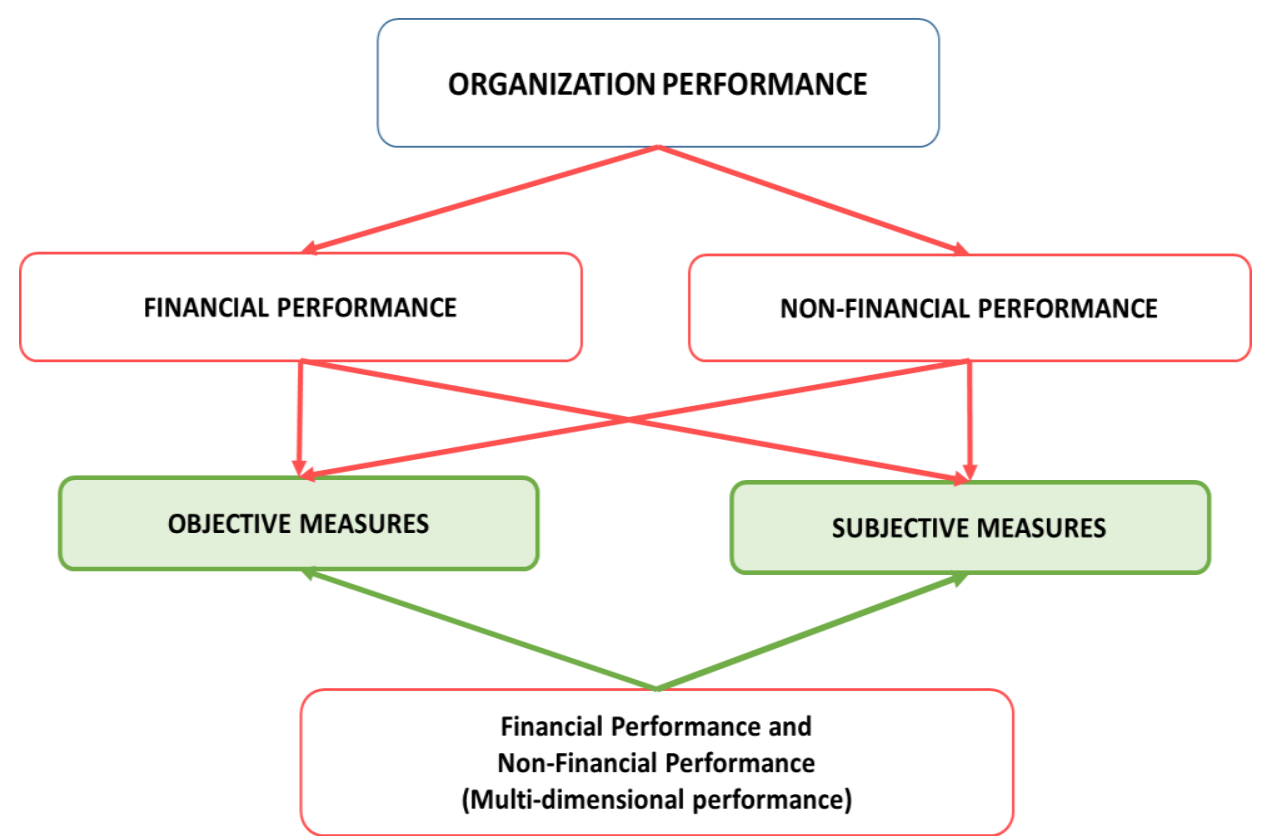

Figure 1: Performance Indicator Classification 
Table 1: Performance Indicators Related to Intellectual Capital and Innovation Capability Studies

\begin{tabular}{|c|c|c|c|}
\hline $\begin{array}{l}\text { Authors } \\
\text { (Year) }\end{array}$ & Title & $\begin{array}{l}\text { Type of } \\
\text { performanc } \\
\text { e }\end{array}$ & $\begin{array}{l}\text { Performance } \\
\text { Indicators }\end{array}$ \\
\hline $\begin{array}{l}\text { Kamukama et } \\
\text { al. (2011) }\end{array}$ & $\begin{array}{l}\text { Competitive advantage: } \\
\text { mediator of intellectual } \\
\text { capital and performance }\end{array}$ & \multirow{3}{*}{$\begin{array}{l}\text { Financial } \\
\text { performanc } \\
\text { e } \\
\text { (Objective } \\
\text { measureme } \\
\text { nt) }\end{array}$} & $\begin{array}{l}\text { Portfolio at risk (par), } \\
\text { Net profit ratio, Loan } \\
\text { loss recovery ratio, } \\
\text { Repayment rate, Yield } \\
\text { on the portfolio, Return } \\
\text { on assets (ROA) }\end{array}$ \\
\hline $\begin{array}{l}\text { Maditinos et } \\
\text { al. (2011) }\end{array}$ & $\begin{array}{l}\text { The impact of intellectual } \\
\text { capital on firms' market value } \\
\text { and financial performance }\end{array}$ & & $\begin{array}{l}\text { Market-to-book value } \\
\text { ratios, } \quad \text { Financial } \\
\text { performance }\end{array}$ \\
\hline $\begin{array}{l}\text { Chen et al. } \\
(2020)\end{array}$ & $\begin{array}{l}\text { Should companies invest in } \\
\text { human resource } \\
\text { development practices? The } \\
\text { role of intellectual capital and } \\
\text { organisational performance } \\
\text { improvements. }\end{array}$ & & Return on assets (ROA) \\
\hline Qui & $\begin{array}{l}\text { An exploration of knowledge } \\
\text { management and intellectual } \\
\text { capital in a non-profit } \\
\text { organisation context }\end{array}$ & \multirow{3}{*}{$\begin{array}{l}\text { Non- } \\
\text { Financial } \\
\text { performanc } \\
\text { e } \\
\text { (Subjective } \\
\text { measureme } \\
\text { nt) }\end{array}$} & $\begin{array}{l}\text { Innovation strategy } \\
\text { execution, Innovation- } \\
\text { focused HR policy, } \\
\text { Environmental } \\
\text { uncertainty, Innovation } \\
\text { performance }\end{array}$ \\
\hline $\begin{array}{l}\text { Xiaobo and } \\
\text { Sivalogathasa } \\
\mathrm{n}(2013)\end{array}$ & $\begin{array}{l}\text { Impact of organization } \\
\text { motivation on intellectual } \\
\text { capital and innovation } \\
\text { capability of the textile and } \\
\text { apparel industry in Sri Lanka }\end{array}$ & & $\begin{array}{l}\text { Customer satisfaction, } \\
\text { Market performance, } \\
\text { Expected or existing } \\
\text { earning power }\end{array}$ \\
\hline $\begin{array}{l}\text { Huang, and } \\
\text { Huang, } \\
(2020)\end{array}$ & $\begin{array}{l}\text { External and internal } \\
\text { capabilities } \\
\text { organisational performance: } \\
\text { Does intellectual capital } \\
\text { matter? }\end{array}$ & & $\begin{array}{l}\text { Market knowledge, } \\
\text { Customer knowledge, } \\
\text { Relationship, and } \\
\text { Innovation }\end{array}$ \\
\hline $\begin{array}{l}\text { Oke et al. } \\
(2012)\end{array}$ & $\begin{array}{l}\text { Innovation strategy, human } \\
\text { resource policy, and firms' } \\
\text { revenue growth: the roles of } \\
\text { environmental uncertainty } \\
\text { and innovation performance }\end{array}$ & \multirow[t]{2}{*}{$\begin{array}{l}\text { Multi- } \\
\text { dimensional } \\
\text { performanc } \\
\text { e } \\
\text { (Objective } \\
\text { and } \\
\text { Subjective } \\
\text { measureme } \\
\text { nt) }\end{array}$} & $\begin{array}{l}\text { Actual sales figures or } \\
\text { revenue, Innovation } \\
\text { strategy execution, } \\
\text { Innovation-focused, HR } \\
\text { policy, environmental } \\
\text { uncertainty, and } \\
\text { innovation } \\
\text { performance }\end{array}$ \\
\hline Ritala (2012) & $\begin{array}{l}\text { Coopetition strategy - when } \\
\text { is it successful? empirical }\end{array}$ & & $\begin{array}{lr}\begin{array}{l}\text { Sales } \\
\text { profitability, }\end{array} & \text { growth, } \\
\text { market }\end{array}$ \\
\hline
\end{tabular}




\begin{tabular}{|c|c|c|c|}
\hline $\begin{array}{l}\text { Authors } \\
\text { (Year) }\end{array}$ & Title & $\begin{array}{l}\text { Type of } \\
\text { performanc } \\
\text { e }\end{array}$ & $\begin{array}{l}\text { Performance } \\
\text { Indicators }\end{array}$ \\
\hline & $\begin{array}{l}\text { evidence on innovation and } \\
\text { market performance }\end{array}$ & & $\begin{array}{l}\text { share, and market } \\
\text { growth, Overall success }\end{array}$ \\
\hline $\begin{array}{l}\text { Hsu and Fang } \\
\text { (2009) }\end{array}$ & $\begin{array}{l}\text { Technological forecasting and } \\
\text { social change intellectual } \\
\text { capital and new product } \\
\text { development performance: } \\
\text { The mediating role of } \\
\text { organisational learning } \\
\text { capability }\end{array}$ & \multirow{7}{*}{$\begin{array}{l}\text { Multi- } \\
\text { dimensional } \\
\text { performanc } \\
\text { e } \\
\text { (Subjective } \\
\text { measureme } \\
\text { nt) }\end{array}$} & $\begin{array}{r}\text { Market performance, } \\
\text { Financial performance, } \\
\text { Customer } \\
\text { performance, Product } \\
\text { performance }\end{array}$ \\
\hline $\begin{array}{l}\text { Sharabati et } \\
\text { al. (2010) }\end{array}$ & $\begin{array}{l}\text { Intellectual capital and } \\
\text { business performance in the } \\
\text { pharmaceutical sector of } \\
\text { Jordan }\end{array}$ & & $\begin{array}{l}\text { Productivity, } \\
\text { Profitability, Market } \\
\text { valuation }\end{array}$ \\
\hline $\begin{array}{l}\text { Hormiga et } \\
\text { al. (2011a) }\end{array}$ & $\begin{array}{l}\text { The impact of relational } \\
\text { capital on the success of new } \\
\text { business start-ups }\end{array}$ & & $\begin{array}{l}\text { Return on investment } \\
\text { (ROI), } \\
\text { Achievement, Initial } \\
\text { goals, The overal } \\
\text { success, Success in } \\
\text { comparison with } \\
\text { competitors }\end{array}$ \\
\hline $\begin{array}{l}\text { Saunila } \\
\text { (2016) }\end{array}$ & $\begin{array}{l}\text { The relationship between } \\
\text { innovation capability and } \\
\text { performance: } \\
\text { moderating effect of } \\
\text { measurement }\end{array}$ & & $\begin{array}{l}\text { Financial and } \\
\text { operational } \\
\text { (productivity, quality, } \\
\text { etc) }\end{array}$ \\
\hline $\begin{array}{l}\text { Chen et al. } \\
(2014)\end{array}$ & $\begin{array}{l}\text { Intellectual capital and new } \\
\text { product development }\end{array}$ & & $\begin{array}{l}\text { Relative return on } \\
\text { investment and } \\
\text { relative profitability, } \\
\text { Relative market share } \\
\text { and relative sales, } \\
\text { Meeting objective for } \\
\text { customer satisfaction }\end{array}$ \\
\hline $\begin{array}{l}\text { Chen and } \\
\text { Wang (2015) }\end{array}$ & $\begin{array}{l}\text { A new measurement of } \\
\text { intellectual capital and its } \\
\text { impact on innovation } \\
\text { performance in an open } \\
\text { innovation paradigm }\end{array}$ & & $\begin{array}{l}\text { Financial performance, } \\
\text { Technical competence, } \\
\text { Opportunity windows }\end{array}$ \\
\hline $\begin{array}{l}\text { Alrowwad, } \\
\text { and } \\
\text { Abualoush } \\
\text { (2020) }\end{array}$ & $\begin{array}{l}\text { Innovation and intellectual } \\
\text { capital as intermediary } \\
\text { variables } \\
\text { transformational leadership, } \\
\text { transactional leadership, and } \\
\text { organisational performance. }\end{array}$ & & $\begin{array}{l}\text { Financial Perspective, } \\
\text { Customer Perspective, } \\
\text { Internal Process } \\
\text { Perspective, and } \\
\text { Learning and Growth } \\
\text { Perspective }\end{array}$ \\
\hline
\end{tabular}


Table 1 above, presents the literatures related to the performance indicators related to intellectual capital and innovation capability from various filed across the world. The indicators used to measure performance are either objective measures or subjective measures using financial performance or non-financial performance. However, it cannot be denied that some of the latest literatures are employing multi-dimensional performances.

\section{Conclusion}

As a result, the implications of the research for both researchers and practitioners revealed the measurement instrument that researchers prefer in terms of intellectual capital and innovation capability. However, it's worth noting that the instruments are typically chosen based on the study's target as well as the instrument's popularity in this field. Researchers should proceed with caution when choosing an instrument to measure organisational performance because the instrument has a direct effect on the study's outcome. Future research should look at all the variables that could affect findings related to intellectual capital, innovation capacity, and organisational performance.

As a result, the research's implications for both academics and practitioners can be split into few categories. Firstly, the study uncovered the research instrument that is preferred by researchers. One of the most significant aspects of instrument selection is that the reasons for selecting the instruments are generally dependent on the popularity of the instrument and based on the objective of the study. Based on this observation, it is suggested that researchers should be more cautious when selecting the tool for measuring organisational performance because the tool has a direct impact on the outcome of the study.

Secondly, the discovery highlights the fact that the method in which the instruments are used can affect the results of the research. In other words, when subjective measures of organisational performance are used, the outcome of the results is known well in advance. Whereas using objective measures leads to an increase in the variability of the results, the degree of subjectivity has a negative impact. A result of this is that researchers and practitioners should be more aware of the possible false inferences that may arise from using a specific method to measure organisational performance, particularly the use of subjective measures.

\section{References}

Alrowwad, A. A., \& Abualoush, S. H. (2020). Innovation and intellectual capital as intermediary variables among transformational leadership, transactional leadership, and organizational performance. Journal of Management Development.

Battor, M., and Battor, M. (2010). The Impact of Customer Relationship Management Capability on Innovation and Performance Advantages: Testing a Mediated Model. Journal of Marketing Management, 26(9-10), 842-857.

Chen, J., and Wang, Y. (2015). A New Measurement of Intellectual Capital and its Impact on Innovation Performance in an Open Innovation Paradigm. International Journal of Technology Management, 67(1), 1-25.

Chen, C. J., Liu, T. C., Chu, M. A., and Hsiao, Y. C. (2014). Intellectual Capital and New Product Development. Journal of Engineering and Technology Management, 33, 154-173. 
Chen, M. Y. C., Lam, L. W., \& Zhu, J. N. (2020). Should companies invest in human resource development practices? The role of intellectual capital and organizational performance improvements.

Dawes, J. (1999). The Relationship between Subjective and Objective Company Performance Measures in Market Orientation Research: Further Empirical Evidence. Marketing Bulletin, 10(3), 65-75.

Gentry, R. J., and Shen, W. (2010). The Relationship Between Accounting And Market Measures Of Firm Fnancial Performance: How strong is it? Journal of Managerial Issues, 4(22(4)), 514-530.

Greenley, G. E. (1995). Market Orientation and Company Performance: Empirical Evidence from UK Companies. British Journal of Management, 6(1), 1-13.

Huang, C. C., \& Huang, S. M. (2020). External and internal capabilities and organizational performance: Does intellectual capital matter? Asia Pacific Management Review, 25(2), 111-120.

Hormiga, E., Batista-Canino, R. M., and Sánchez-Medina, A. (2011b). The role of Intellectual Capital In The Success of New Ventures. International Entrepreneurship and Management Journal, 7(1), 71-92.

Huselid, M. A. (1995). The Impact of Human of Human Resource Management Practices on Turnover, Productivity, and Corporate Financial Performance. Academy of Management Journal, 38(3), 635-672.

Hsu, Y. H., and Fang, W. (2009). Intellectual Capital and New Product Development Performance: The Mediating Role of Organizational Learning Capability. Technological Forecasting and Social Change, 76(5), 664-677.

Kamukama, N., Ahiauzu, A., and Ntayi, J. M. (2011). Competitive Advantage: Mediator of Intellectual Capital and Performance. Journal of Intellectual Capital, 12(1), 152-164.

Kaplan, R. S., and Norton, D. P. (1996). The Balanced Scorecard: Translating Strategy Into Action. Harvard Business School Press, Boston, MA

Likar, B., Kopač, J., and Fatur, P. (2014). Innovation Investment and Economic Performance in Transition Economies: Evidence from Slovenia. Innovation: Management, Policy and Practice, 16(1), 53-66.

Maditinos, D., Chatzoudes, D., Tsairidis, C., and Theriou, G. (2011). The Impact of Intellectual Capital on Firms' Market Value and Financial Performance. Journal of Intellectual Capital, 12(1), 132-151.

McWilliams, A., and Siegel, D. (2000). Corporate Social Responsibility and Financial Performance: Correlation or Misspecification? Strategic Management Journal, 21(5), 603-609.

Mention, A. L. (2012). Intellectual Capital, Innovation and Performance: A Systematic Review of the Literature. Business and Economic Research (BER), 2(1), 1-37.

Oke, A., Walumbwa, F. O., and Myers, A. (2012). Innovation Strategy, Human Resource Policy, and Firms' Revenue Growth: The Roles of Environmental Uncertainty and Innovation Performance. Decision Sciences, 43(2), 273-302.

Özer, G., Ergun, E., \& Yilmaz, O. (2015). Effects of intellectual capital on qualitative and quantitative performance: Evidence from Turkey. South African journal of economic and management sciences, 18(2), 143-154.

Palumbo, F., and Laurenziano, C. (2013). University Incubator as Catalyst of Resources for Academic Spin-offs. The case of ARCA Consortium. Proceedings of the 1st International 
Conference on Management, Marketing, Tourism, Retail, Finance and Computer Applications (MATREFC'13). Dubrovnik, Croatia., 209-218.

Perin, M. G., Sampaio, C. H., Jiménez-Jiménez, D., and Cegarra-Navarro, J. G. (2016). Network Effects on Radical Innovation and Financial Performance: An Open-Mindedness Approach. BAR-Brazilian Administration Review, 13(4), 1-24.

Quink, U. (2008). An Exploration of Knowledge Management and Intellectual Capital in A Nonprofit Organisation Context. Doctor of Philosophy (PhD), Queensland University of Technology.

Rajan, M. V., and Reichelstein, S. (2009). Objective Versus Subjective Indicators of Managerial Performance. The Accounting Review, 84(1), 209-237.

Ranani, H. S., and Bijan, Z. (2014). The Impact of Intellectual Capital on the Financial Performance of Listed Companies in Tehran Stock Exchange. International Journal of Academic Research in Accounting, Finance and Management Sciences, 4(1), 119-127.

Ritala, P. (2012). Coopetition Strategy-When is it Successful? Empirical Evidence on Innovation and Market Performance. British Journal of Management, 23(3), 307-324.

Santos, J. B., and Brito, L. A. L. (2012). Toward a Subjective Measurement Model for Firm Performance. BAR-Brazilian Administration Review, 9(SPE), 95-117.

Saunders, M., Lewis, P., and Thornhill, A. (2012). Research Methods for Business Students, 6th Edition. Essex: Pearson.

Sethibe, T., and Steyn, R. (2016). Innovation and Organisational Performance: A critical review of the Instruments used to Measure Organisational Performance. The Southern African Journal of Entrepreneurship and Small Business Management, 8(1), 1-12.

Sharabati, A. A. A., Jawad, S. N., and Bontis, N. (2010). Intellectual aapital and Business Performance in the Pharmaceutical Sector of Jordan. Management Decision, 48(1), 105-131.

Shin, Y., Sung, S. Y., Choi, J. N., and Kim, M. S. (2014). Top Management Ethical Leadership and Firm Performance: Mediating Role of Ethical and Procedural Justice Climate. Journal of Business Ethics, 129(1), 43-57.

Singh, S., Darwish, T. K., and Potočnik, K. (2016). Measuring Organizational Performance: A Case for Subjective Measures. British Journal of Management, 27(1), 214-224.

Tsao, S. M., and Lien, W. H. (2013). Family Management and Internationalization: The Impact on Firm Performance and Innovation. Management International Review, 53(2), 189213.

Tseng, M. L., Wang, R., Chiu, A. S., Geng, Y., and Lin, Y. H. (2013). Improving Performance of Green Innovation Practices under Uncertainty. Journal of Cleaner Production, 40, 7182.

Venkatraman, N., and Ramanujam, V. (1986). Measurement of Business Performance in Strategy Research: A Comparison of Approaches. Academy of Management Review, 11(4), 801-814.

Xiaobo, W., and Sivalogathasan, V. (2013). Innovation Capability for better Performance: Intellectual Capital and Organization Performance of the Apparel Industry in Sri Lanka, 1(3), 273-277. 